\title{
Gender Disparity in Education, Employment and Access to Productive Resources as Deterrent to Economic Development
}

\author{
Agnes S. Antai (Corresponding author) \\ Institute of Public Policy and Administration \\ University of Calabar, Calabar, Nigeria \\ Email: Agnes S. Antai \\ Bassey Anam \\ Institute of Public Policy and Administration \\ University of Calabar, Calabar, Nigeria
}

Received: September 08, 2016 Accepted: October 04, 2016 Published: October 08, 2016

doi:10.5296/jpag.v6i3.10090 URL: http://dx.doi.org/10.5296/jpag.v6i3.10090

\begin{abstract}
World over, equality in education, employment and access to productive resources have been noted as needed indicators for economic development. Education has been recognized as a fundamental human right and is signatory to the major conventions for the protection of the rights of children and women, especially, the Convention on the Rights of the Child (CRC), and the Convention on the Elimination of all forms of Discrimination against Women (CEDAW). In 2003, the Government of Nigeria passed into Law the Child rights Act. This act is aimed at facilitating the realization and protection of the rights of all children. In the quest to achieve the objectives of Education For All (EFA) and Millennium Development Goals (MDGs), Nigeria also enacted the Universal Basic Education (UBE) law, which provides for a 9-year free and compulsory basic education to fast-track education interventions at the primary and junior secondary levels. So also has been the trend with employment and access to productive resources. The question posed here is, how has these policy efforts been attainable? Is it because of the policies are not duly formulated, or duly formulated but poorly implemented, or both? There are still challenges on gender and geographic disparity, access to formal education, sex preferences, employment discretion, and access to productive resources where needful and useful. Faced with these discrepancies, the
\end{abstract}


researchers dare to assess the various trend and causes of this disparity among these three units thereby suggesting attainable methodology which would help reduced the problem projecting sustainable growth for the nation.

Keywords: Gender disparity, Economic development, Education sector

\section{Introduction}

The trend and concern over gender issues in the country dates years back. In Nigeria, as well as other developing and even developed nations of the world, the prevalence of gender gap has been subjected to debates, consultations and deliberations in an effort to reduce its influence among various sectors in the society. Education and other sectors as well will be discussed. Lots of discrepancies have been noted as gaps between the education of males to females. There seems to be more preferences and this has militated against proper developmental efforts in the nation. As in the rest of the world, girls and women are frequently victimized simply because they are females. The underlining factor we believe is the underscoring perception as regards the womanhood. It becomes useful in providing an explanation of the opportunity structures available to men and women for self-actualization and effective participation in the development process. In discussing the perception of womanhood, the idea refers to beliefs, notions and ideas people have about females in terms of what they represent in their relationship to men as well as expectations about appropriate female roles. Generally, perceptions are culturally constructed and are therefore products of the socialization process. Writing on "Women's Experiences in Labour Force Participation", Nkoli(2005) reported, Women participation in paid employment for a long time was characterized by female dominance in lower cadre jobs and minimal participation in executive, administrative, scientific and technological professions. A major constraint was due to initial disparity in access to education along gender lines, which dated from the colonial period. That disparity has been attributed to early missionary and colonial educational policies, which favoured homebound education for women (Fafunwa, 1974; Mann, 1985) and attitudes of local people to female education. Robertson (1986:93) reported that in Africa, colonialists as well as local people used gender as the criterion for decisions on access to education. She further explained that the trend was influenced by people's perception of women's roles as secondary and domestic. Hence, during the colonial period, while men were being trained as policemen, clerks, teachers and catechists, women received education which was biased in favour nutrition, child care and home management. The idea was to prepare women as wives for the male elite (Mba, 1982). Females participated only in positions that the colonial government regarded suitable for them. These were in prisons, medical, education and later in printing and telegraph departments (Denzer, 1987). This, one would argue had given rise to the continuing problems of inequalities. However, concerns to this have not been retarded.

In this bit, in 1990 in Jomtien, Thailand, at the World Conference on Education for All, world leaders agreed that "the most urgent priority (was) to ensure access to, and improve the quality of, education for girls and women, and to remove every obstacle that hampers their 
active participation". A deadline was set: universal access to, and completion of, primary education should be achieved by the year 2000. By the year 2000, this "urgent priority" had not been realized. In the World Education Forum, held that year in Dakar, new deadlines were fixed: all children should complete "compulsory primary education of good quality" by 2015 , and participants once again expressed specific concern about gender disparities in education, pledging to eliminate them by 2005. At the UN's Millennium Summit, heads of state adopted these targets at two of the eight Millennium Development Goals for reducing world poverty. The Global Campaign for Education, an international coalition of NGOs and trade unions, states "because education is so crucial to improving health and increasing incomes, the girls' education goal has a domino effect on all of the other Millennium Development Goals. Failure to achieve it will set us up for almost certain failure on other MDGs". The Global Campaign for Education claims that if donors and governments fulfill their commitment, this objective can be achieved. "The problem is not over-ambition, but lack of ambition", they say. And they are carrying out an international campaign to raise awareness and pressure governments (Save the Children Campaign, March 2006). On employment, the concern had not differed. Gender gaps in employment imposed distortion on the economy. If artificially reduces the pool of talents from which employers can draw, thereby reducing the average ability of the workforce. Gender gaps in access to managerial positions and employment more generally distorts the allocation of talents and the production and productivity of human capital, all of which serves to reduce economic growth.

Resulting from this trend, the large contribution of women to measured Gross Domestic Product (GDP) is largely driven by their large disproportionate role they play in the agricultural sector. This acknowledged differential position has constrained this position. Though undermined, their relevance is further noted in the industrial sector. The share of female employment in the industrial sector is generally much smaller, with very few exceptions such as textile and garment industries in a few African states with Nigeria in focus. This position will be made clearly with concern on the framework of distinction on formal and informal employment. This distinction can be deduced from the data and other studies, which have indicated that women employment has been relegated to non-technical and highly sensitive operational units. This represents a rather heterogeneous mix of public services, community and health services, and as many services provided in the informal sector. Borrowing international indicators, excluding South Africa, the share of informal employment in non-agricultural employment is $78 \%$. If agriculture is included, this rises to 83\%. Self-employment represents $70 \%$ of informal employment and $53 \%$ of total non-agricultural employment. Outside of agriculture, more than $60 \%$ of women are in informal employment. Although women's participation rates are lower compared with men, they are important in street vending (90\%), home-based workers (80\%) and as home workers (80\%) (Sudharshan, 2005). With respect to access to productive resource, the concern has not been relegated. In situations where women and men undertake different and/or separate productive activities (as is the case in agriculture in Africa but also in non-agricultural activities in many developing countries), differential access to productive assets and inputs forms a distortion in the sense that 'women activities' are (comparatively) over-resources and under-resourced and undercapitalized. Due to declining marginal returns and/or the loss 
associated with talented women being starved of economic resources, such a distortion reduces aggregate. Such disparity might not only lead to static inefficiency but also reduce efficient investments in new technologies and the maintenance and improvement of assets including particularly land. Judging from the above discrepancies, the paper lays out the case that gender disparity plays a significant role in accounting for Nigeria's poor growth and poverty reduction and thus argues that removing this disparities would be an important precondition for addressing Nigeria's growth problem and perhaps other developing nations as will be useful in their context. Complemented with considerable micro evidence, this paper reviews recent empirical research that analyzes cases of gender disparity in education employment and access to productive resources, examines the causes and implications of these disparities and then considers relevant measures to address the present upheaval.

\section{Gender Disparity in Education}

Education is defined as the aggregate of all the processes in which a child or young adult develops abilities, attitudes and other forms of behavior which are of positive values to society in which he lives. Education has been relegated as been needful more to the male child at the detriment of the female. In other words, the life-long process, which individuals acquire the relevant knowledge, which enables them, fit into not just the society but become useful to them and the society at large is considered relevant to the male child. This ought not to be the case. The need to educate the young child and woman should be seen essential to all irrespective of sex or gender. From the Commonwealth Secretariat, the 2005 Human Development Report noted with concern that had this goal been achieved, 14 million girls would be in school right now. Of those, 6 million are in India and Pakistan alone, with another 4 million in Africa. The report's statistical tables outlined progress that has been made in many countries since 1990, but despite this, Commonwealth South Asia and sub-Saharan Africa continue to exhibit female net enrolment rations at both the primary and secondary level that tell us the problem will persist for some years to come. As such, eliminating gender disparity by increasing access to education for girls is ultimately integral to the attainment of the 2015 .

\subsection{Education MDG on Universal Primary Education}

Barriers towards girls' access and retention in primary and secondary school are myriad and vary between countries and regions, although there are some commonalities throughout the Commonwealth countries that experience the problem. The secondary position of women in most patriarchal societies translates itself into viewing of education as not beings as important for girls. Socioeconomic and cultural factors play a part, and in some cases, families favour boys over girls for entrance into school, especially if access to quality education is not free. More generally, the broader obstacle of poverty continues to keep girls (and boys) in varied labour environments in order to help their families subsist. In other situations, the fear of girls being exposed to unacceptable practices in co-educational schools - such as sexual orientation that could result in pregnancy, or violence and general harassment - prevent parents from allowing their female children to access basic schooling. These same factors can also contribute to the rise of girls dropping out of school in some 
countries as they move through the education system. In many cases, statistics put forward by the Human Development Report showed that those countries where disparity in girls' enrolment could be seen at primary level exhibited an even more increased disparity at secondary level. Initiatives towards tackling these issues within the Commonwealth therefore need to be far-reaching, and require coordinated efforts both at the government and community level within countries. Concerted efforts towards including programmes that tackle gender disparity within broader education plans are needed, while local-level initiatives that tackle particular cultural and social specificities also need support. The provision of more qualified female teachers is one consideration that could go some way to eliminating some of the cultural factors preventing girls from accessing school, while more single-sex schools for girls in certain specific situation sis potentially another. The process of education, including the curriculum, needs to focus on empowerment and equity issues. Conversely, the secretariat is now also becoming increasingly aware of the problems of boy's underachievement in some countries. The problem is being focused primarily among the Commonwealth high and middle-income countries, although some low-income countries are also noting similar patterns where male school children start to underachieve from the late primary/early secondary school grades. So far, factors such as a lack of male role models, changing gender perceptions, economic obligations, and out-modeled curriculum have been suggested. The issues however are complex, and a much deeper analysis is needed in order to put the problem within the broader context of overall gender equity. Further, Carol Bellamy (UNICEF Executive Director) in his policy statement noted, it is our commitment that no girls will be left behind as her country attempts to move forward, and that every girl will be educated to assume her rightful place as an agent in her country's development. With girls' education as one of its priorities, UNICEF is working with governments and a range of partners to achieve robust and sustainable gains in gender parity in primary and secondary education. To this end, we have launched a major new initiative to intensify efforts in 25 countries to maximize the number of girls in schools. The lessons learned during this period will be applied to accelerating girls' education in other countries until all the world's children enjoy their right to quality education. In identifying the 25, UNICEF looked for one or more of the following: low enrolment rates for girls (less than 70\%), gender gaps of more than $10 \%$ in primary education, countries with more than 1 million girls out of school, countries included on the World Bank's Education for All Fast Track Initiative, and countries hard hit by a range crisis that affect school opportunities for girls, such as HIV/AIDS and conflict. Among other countries sharing in the acceleration strategy, Nigeria is involved. Still on the foreign scene, evidence across regions in the world reveals patterns in school enrollment ratios and literacy that are divided along gender lines. In the developing world, apart from most countries in Latin America and the Caribbean, enrollment ratios of girls lag behind those for boys at all levels of education. Worldwide literacy rates for adult men far exceed those for women. While educational progress has been enjoyed by both sexes, these advances have failed to eradicate the gender gap. Education enhances labour market productivity and income growth for all, yet educating women has beneficial effects on social wellbeing not always measured by the market. Rising levels of education improve women's productivity in the home, which in turn can increase family health, child survival and the investment in 
children's human capital. The social benefits from women's education range from fostering economic growth to extending the average life expectancy in the population, to improving the functioning of political processes (Anne, 1995). These have not been fully reconciled in Nigeria due to disperse upheaval. The latest data show signs of progress in terms of greater gender parity at the primary level, but gaps are still wide at the secondary level. The Global Education Digest 2005 reminds the reader that gender differences in secondary education are accumulated across education levels - and reflect levels of gender parity in participation and completion at the primary level from the mid-1990s. Latest figures from the Digest reveal that:

Globally, gender disparity levels are almost equal at the primary and lower secondary levels, some $56 \%$ of children live in countries with disparity in primary enrolment ratios and $58 \%$ live in countries with disparity in lower secondary education.

However, the difference between girls and boys rises dramatically at the upper secondary level, where nearly nine out ten $(87 \%)$ children live in countries with gender disparity.

At the primary school level, $13 \%$ of children lie in countries with rates of gender disparity - where for every 100 boys fewer than 85 girls are enrolled (the Gender Parity Index - see below-is less than 0.85).

In lower secondary education, one-third of all children live in countries with large disparities favouring boys (GPI is less than 0.85 ). Conversely, some $13 \%$ of children live in countries where enrolment rations favours girls.

In upper secondary education, only $13 \%$ of the school age population lives in countries where girls and boys have equal access. Girls are the most disadvantaged in Africa and Asia.

Gender disparities against girls are highest in Benin, Cote d'Ivoire, Ethiopia, Guinea, Mali and Togo, with fewer than 60girls per 100 boys entering secondary education. These gender disparities reflect those that start primary education. Nigeria is to left out of this context.

Evidently, back home in 2005, Mrs. Chinwe Nora Obaji, the Honourable Minister of Education, Nigeria in a consultative forum at China spoke, Gender equity in education has been one of the main goals targeted by Nigeria since the 1990 World Conference on Education For All (EFA), in Jomtien, Thailand. This commitment has been renewed in several international for a, including the United Nations Decade for Girls' Education Initiative (UNGEI). In Nigeria, there is a national gender disparity in basic education enrolment, retention and completion against girls. In addition there are regional variations in gender disparity in education with girls and women from Northern Nigeria and rural communities generally at a disadvantage. Nigeria is in no doubt a patriarchal society, which places a high premium on the male populace and relegates to the background the women folk and their contributions to national development (Akpan, 1996). Right from infancy, the female child is seen largely by Nigerian society as a mistake and an undesirable to the family beause she will not be able to carry on the family name (Oroka, 1996). Consequently, the female child is consigned to the background and given very minimal attention or even education. In the opinion of Asun, Baklit and Okoye (1997), women are given fewer 
educational opportunities than men in Nigeria, as reflected in the lower literacy rates for the adult female population compared to men. Factors such as male chauvinism, child labour, early marriages, religious and socioeconomic factors combine to increase drop-out rates of girls from school to as much as $36 \%$, even before completion of primary school education (Aziza, 1996). The male preference in education also tended to result in higher dropout rates for girls either for early marriage or for participation in trading or other activities in the informal sector. Even where girls continued in education there had been the tendency for them to be oriented by their parents or relations to pursue careers that are perceived to be compatible with domestic responsibilities. Hence girls were often discouraged from going into scientific and technological fields. This is because such fields are perceived to be male professions that time demanding and stressful. Consequently girls are encouraged to pursue perceived soft courses in Humanities and Social Sciences. Often girls are cautioned about their career choices for fear of not getting married because "mean are scared of smart women". One of the consequences of pursuing the so-called soft courses is that many girls end up getting employed in the female dominated profession such as nursing, teaching and secretarial jobs which attract less wages in comparison with employment in scientific and technological areas.

By 1960, when Nigeria became independent only $4.7 \%$ of those employed in civil service were women, majority of whom were serving in the lower cadre (Ighodalo, 1990). By 1970, about $60.8 \%$ of Nigerian women were still illiterate (Robertson, 1986: 97). The tendency for sex typing in occupations tended to continue until the early 1980s (Aweda, 1988). Part of the reason for the persistence of the sex typing in occupation was due to women's lack of expertise in scientific and technological skills. Changes in educational policies since the mid-1980s as well as in attitudes of parents, relations and teachers towards female education are leading to improved opportunities for skill training and professional development for women. This trend is resulting in the bridging of the gender gap in access to education. As a result, the number of women in executive cadre both in private and public sectors is increasing. We do hope this will be sustained. From this backdrop, one implication of the low human development rating given to Nigeria by UNDP is that her focus on the male members of society rather both sexes in educational activities has resulted in a minimal level of human development. In the opinion of Mataga and Abdullahi (2002), education is an instrument par excellence for effective national development. It is also the greatest investment that the nation can make for the quick development of its economic, political, sociological and human resources. If this is agreeable, it holds therefore that Nigeria should undermine preferential treatment but uphold equality so that all may have access to it as such contribute to the common development of the nation.

\section{Gender Disparity in Employment and Access to Productive Resources: Deterrent to Economic Development}

Widely acclaimed, persistent inequality between men and women constraints a society's productivity and ultimately slows its rate of economic growth. The economy pays for this inequality in reduced labour productivity today and diminished national output tomorrow. This truth has a myriad of other important consequences, including psychological, 
sociological, and sociological, and religious, these are not discussed in this paper. However, the viewed shared discloses that effective economic development strategy depends critically on promoting productivity and output growth in the agricultural sector, particularly among small-scale producers. Moreover, if farmers were making use of existing technology, then efforts designed to improve efficiency would be more cost-effective than introducing new technologies as a means of increasing agricultural output. The above accession reveals the role female labor in agricultural production which significantly affect growth rate. But then, a better place to begin is enhancing equalities among all individuals, especially concern on the female factor. Although socialization of women into positions and roles that are different from those of men is a universal practice, it has resulted in greater inequality and female subordination in sub-Saharan African societies than in most other societies in the world. Gender stratification results in gender inequality, inequality in prestige, inequality in decision making powers and inequality in access to resources. Although there may be difference in matters of women subordination and economic dependence across African societies, these are matters of degree rather than kind. In both cases, a higher female share is assumed to be indicative of an improvement in labor standards. Measured in these ways, neither Kucera (2001) nor Busse find evidence of a negative effect of an improvement in labour standards on FDI and comparative advantage, respectively. While this might appear to be good news at first sight, the measures these authors use to capture in improvement in gender equity are inadequate to reflect the way that investment, trade, gender, and labor standards interact. The problems that women face improving their relative economic status is less a function of job access than of job segregation coupled with lack of bargaining power to raise their wages in the jobs they can get. Jayati (2001) had also observed, the dual burden of women workers employed in low-paid flexible and irregular work, with caring responsibilities in the home, further heighten the risk of women to poverty. Within globalizing sectors such as export promotion zones (EPZ) and informational communications technology (ICT) sectors, employers prefer women workers who are willing to accept informal work, work longer than standardized hours and are discouraged from unionizing. These trends cumulatively refer to the 'feminization of labour', which involves rising female employment but with increasing informality of working conditions. Parrenas (2001) argued on this implication. Due to the care deficit in the household when well-paid working mother are unable to care in the home, an informal network of care arrangement are created with extended family member (mostly grandmothers) and formal care provision by maids, nannies and servants. This has led to the creation of a class-hierarchy between the hi-tech 'mistress' in the new global economy and the low-paid 'maid', where the rich women work and the poor women for her children (Young, 2001). Taking another look at the international society, the problem appears all embracing. The Uruguayan report notes the different dimensions of labour inequality: "Women are particularly affected by labour market flexibility, loss of clear work standards, fear of unemployment, gender, labour segmentation, unequal remuneration for the same work, exclusion from decision-making positions due to gender stereotyping, sexual harassment, and a social security system which does not take into consideration the aging population or the informal labour market". India's report is also enlightening on the subject: "women are also marginalized because they are powerless in different economic, social and political activities. 
Legal provisions and social practices regarding ownership and inheritance are weighted against women, except in a few areas where matrilineal family structures exist. Social, political and family structures do not include women in decision-making. This not only affects the place of women in society, the economy and the family, but also contributes to their low self-esteem".

The effects of these processes in the labour market are visible in income gaps even in developed countries. This is the case in Germany. "If women's wages in Germany continue to move into line with men's at the same rate as over the last 40 years, it will take another 40 years, at least for women white-collar workers and far more than 70 years for women in manual jobs, to catch up with their male co-workers”. Averaged across all occupational groups, women are still paid $20 \%$ less than their male co-workers for doing the same work. For female engineers, the difference amounts to $30.7 \%$. Women have limited access to credit. Since from the start they lack financial empowerment, thy must approach credit facilities in their countries to support their economic activities. However credit institutions where available are reluctant to extend their services to them. The reluctance stems from a prejudice that women are bad managers of funds and would not be able to repay loan. Those willing to extend services to women insist on male guarantors. These disperse cases on education, employment and access to productive resources shows lots of delay in economic development. If we see gender as the socially constructed attributes of an individual, related to his or her sex, there is almost always gender differentiation in any given context, where one is seen as either male or female and treated as such. Such differentiation of course does not necessarily always translate into discrimination or disadvantage. They range widely across all aspects of life including mortality inequality, fatality inequality, basic facilities inequality, special needs inequality, professional inequality, ownership inequality and within household inequalities. With this overview of the main debates concerning the relationship between gender inequalities, specific focus will be given to its causes.

\section{Causes of Gender Disparity on Education, Employment and Access to Productive Base}

For each of the areas discussed above, a better way to examine relevant measures at reducing the problem will be better address with first a close look of the causes of these disparities. To this end, among other factors, the following are looked at:

\subsection{Poverty}

Poverty has been a major factor in the chronic under-enrolment of all pupils, especially girls. Poverty affects men, women, boys, and girls, but people of different ages, ethnicities, family roles and sex experience it differently. Due to women's biology, their social and cultural gender roles, and culturally constructed subordination, they face disadvantageous conditions which accumulate and intensify the already numerous effects of poverty. Many parents are so poor that they pull their children out of school for income-generating activities, rather than paying for their children's school fees so as to sustain their families. In such cases, non-formal training can improve both literacy and employment prospects by providing "second chance" education to take care of dropouts. Aside school fees, expenses relating to 
transport, clothing and books widen the gender gap as families cannot afford to educate all their children, girls are the ones that stay at home, helping with household chores. With sexual harassment, to which girls and women are exposed, both on the way to and inside the schools, early marriage and adolescent pregnancy occur. The case is also true on employment consideration on female productive capability. Since there is some evidence of inequality in the agricultural sector due to poverty, particularly among poor producers, it reduces production level. Certain micro elements point out that these inequalities in access to productive assets (such as land, fertilizer, seeds, credits, etc., reduce the productivity of female producers and most often by more than the same inequality increases the productivity of male producers), this particularly contributes to increase the existing poverty level. It also complicates the already existing indices of dependency, which already has noted before forms one of the indicators of a poor economy (Antai and Anam, 2014).

\subsection{Cultural and Social Perceptions and Attitudes}

Apart from poverty, Helen (2003) indicated three other areas as are discussed below. Cultural attitudes such as early marriage, that pregnancy and child bearing are the "ultimate fulfillment of womanhood, particularly when accompanied by marriage" is contributing to the replication of gender stereotypes. In some African countries initiation ceremonies as girls pass into womanhood are significant events. After these initiation rites, there is often a shift in attitude by the girls themselves away from school and studies to boyfriends and sexual relationships. Girls are also often taught to be subservient to their husbands and to willingly accept their subordinate status. When it comes to employment, there are cases of ethnic considerations. Language plays a big role in issues on gender disparity. Language use is a social practice acting as a shaper of other practices within the society. The relationship between social practices (linguistic practices and gender roles/relations/identities) is a dialectal one, a two-way process. This means that language both influences and is influenced by societal practices including those pertaining to gender. This ill has undermined opportunities of qualified individuals who lack cultural identity in a particular geographical or ethnic origin. As a result of cultural bias, adults' expectations vary with respect to boys and girls. Even teachers often see a difference in potential between boys and girls, especially in technical areas. In problem situations where students appear stumped, adults tend to rescue girls by giving them either easy clues or by blatantly revealing the answer. With boys, however, the general practice s to force them to figure it out themselves. Research shows that this kind of "help" undermines girls' confidence in their abilities. Because of different self-esteem levels, boys and girls come to very different conclusions about themselves, even when the data on which they base their decisions are the same. Studies have demonstrated that boys accept success and take credit for the accomplishments more readily than girls. The combination of the facts that girls are given less chance to independently solve problems, and that girls are harsher in judging their own achievements, has serious effects on the self-confidence of girls. Thus, any differences in achievement may be rooted in these culturally different expectations.

However, while increasingly many women pursue higher education and careers, society still raises its girls with the option not to work for a living. However, current demographic 
statistics point out that nine times as many women as men are single parents, thus forcing more women than before to make a living. Because women have not been directed on career paths from the start, they often must settle for lower level jobs. Thus, women continue to be funneled into traditionally female occupations. In order to keep up with recent technological trends, girls must be introduced at a young age to scientific and engineering fields, else they may enter too late, leaving them only to be trained for more clerical and secretarial aspects of the new technology, for example data entry and low-level computer operation. If this is the case, women will remain at the low end of the service-oriented pay scale. The traditional roles of men and women dictate the focus of that which boys and girls learn in school. Thus, if girls continue to be bypassed when considering technical work, women will never have a stronghold in the technical fields and the traditional views will never be changed. In order to rectify the cycle, these stereotypes must be reevaluated, and girls must be encouraged to pursue more technical careers (Gender Inequalities in Education, 1998). Still on the cultural perspective, women are faced with many challenges and contradictions in their efforts to attain self-actualization. It was pointed out earlier that traditionally resourcefulness and industry are virtues that are inculcated in women and girls. Yet the same society tends to perceive women's attainment of wealth and social status negatively. Aina (1998) reported that among the Yoruba where a women attains a high social status independent of her husband, she is perceived as a with, prostitute or a free woman. The husband of such a woman is consequently disrespected. Aina cited Yoruba expressions such as "O tirani ye" which means that the husband has been bewitched by the wife or "tiso di didirin" which implies that the woman has so bewitched the man that he has lost his intellect. This idea of regarding women's endeavor to gain power, status and wealth in negative terms is not peculiar to Nigeria. Much earlier Kaberry (1952) referred to the reluctance of men in Bamenda, Cameroun to accept the participation of women in male dominated trade. She wrote that the men expressed fears that such a trend might disturb the mutual dependence that existed between husband and wife and undermine the stability of marriage. The men she pointed out feared that women might become moneylenders and no longer homemakers.

\subsection{Achievement}

In Africa, boys have traditionally performed better at school than their female counterparts. But in the Caribbean the situation has reversed. A similar trend is becoming evident in the Pacific, Canada, the United Kingdom and the U.S. In parts of India, girls are beginning to move into non-traditional fields such as engineering and math. They are, however, experiencing a backlash - parents are educating their girls but are now discovering that there is no work for them in their fields of interest and that men do not necessarily want to marry their daughters because they are too educated. Similarly, once they are married, women tend to drop out of the workforce. In Zambia, one of the biggest reasons girls drop out of school is their failure to pass exams and be promoted to the next grade. At the family level, parents tend to view boy's education as ultimately more cost effective as girls usually join their husband's family once they are married. 


\subsection{Curriculum Design}

Relating further concern, Helena (2003) also disclosed, while participants agreed that changes in curriculum and the way gender roles are projected in curriculum materials, it was also noted that males and females have fundamentally different approaches to learning and competing. Research indicates that girls have a higher comfort level when competing as a group versus individually. It was therefore suggested that further research reviews highly competitive professions such as medicine, law, engineering, etc. to see if group/team based evaluations and curriculum approaches improve female enrolment and success rates.

\subsection{Gender-based teaching style}

The school system itself plays a significant role in creating maintaining gender differences. For example, texbooks often represent the gender bias present in society's view of technical fields. Teaching style also perpetuates the gender difference. A study conducted by the American association of University Women revealed that teachers tend to focus more attention on boys, directing more encouragement to them, while girls are often overlooked in class. By this, teachers are apparently unaware of their biased actions traditional teacher training tends to cater to boys interests and behaviors as means of keeping classroom order. Boys generally act out their frustrations in manner often disruptive to the classroom. In contrast, girls predominantly repress their frustrations by withdrawing. Teachers' methods of controlling boys included making contribute often. Thus teachers have inadvertently favored boys to girls in the traditional classroom setting.

\section{The Way Forward}

Projecting useful measures for effective development in the nation, Okoli (2005) discusses below: Development entails role performance and collective participation. A meaningful development aims at increasing the productivity of the populace as well as effective utilization of the human resource potentials. In the process all sources of inequality in resource distribution and allocation should be eliminated so that both genders derive benefit from the endeavors. "There is need for concerted efforts to eliminate the difficulties women farmers experience in access to productive resources. These include access to land, capital, extension services and improved agricultural technologies and training. This measure will be invaluable in ensuring that women's productivity and benefit from their agricultural work are enhanced". Women's access to extension services can be ensured through the use of female extension agents who are more likely to be familiar with the whole spectrum of woman's work in the agricultural sphere and will also have unrestricted access to their fellow women. Women's agricultural productivity can be promoted through the use of public enlightenment programmes that will sensitize them about options available for self-improvement through the adoption of improved agriculture methods. In the sphere of paid employment, it is important to deemphasize gender socialization which hinders goal aspirations of girls and women toward scientific and technological skills. Education is the key to effective emancipation and empowerment of women. Efforts must be made to ensure that girls have qualitative education in all fields not only in the Arts, Education and Social Sciences but also Science, Mathematics and Technology. Progress is already being made in this direction ad 
must be sustained. The leadership potentials of women can only be enhanced through sound education. There is also the need to address the issue of gender discrimination in employment based on employer's perceptions about appropriate roles for women. In particular, the tendency to discriminate against single females in key positions is contrary to the principles of justice and human rights. Similarly, the reluctance in employing married women on grounds of cots related to maternity leave and absenteeism due to domestic responsibilities creates a dilemma for women in fulfilling their obligations as mothers and wives. Public enlightenment efforts are needed to sensitize the populace that child minding and domestic responsibilities are not women's problems but should be undertaken through concerted efforts of both genders. The provision of adequate day care facilities will go a long way in alleviating some of the conflicts women experience in coping with their career and domestic obligations. Finally, there is need for the promotion of positive aspects of the perception of womanhood such as self-control, industry and resourcefulness. Such attributes would promote women's chances of attaining self-actualization in the development process while the harmful ones should be eliminated.

From Helena (2003), the need for equity for all cannot be undermined. By following gender equity guidelines to improve education, it is improved for boys as well as for girls. The goals of better serving girls does not entail neglecting or suppressing boys. By putting boys and girls on an equal plane, the relatively increased valuing of girls will also benefit boys by informing them of the strengths, capabilities and contributions of girls and women. This, in turn, may help decrease the pressure many boys feel to conform to the traditional roles, behaviors and ways of thinking. Eventually, the stereotypes may be counteracted and eliminated, so education may begin to be more gender balanced. Focusing on girls' educational achievements and career aspirations allow society to ensure women economic security, a better quality of life, and more career choices. As a result, the need for social welfare will decrease, since women with inadequate education head most families I poverty. Thus, targeting more equitable educational techniques will not only improve the lives of individual women, but will also advance the community as a whole as having that many more worthwhile contributors. With further efforts to close the gap, gender studies should become part of the curriculum at all levels - both in face-to-face and open and distance learning programme, community based/society oriented programme. Teachers should receive gender training rather than assumptions being made that they are innately aware of the issues of gender and how to tackle them in the classroom. Constructing systems of support for, and mentoring of, women have been successful. Should similar models be used for boys, re-socialize all members of society, beginning at the family level, co-education schools whereby attitudes can be changed and assumptions challenged beginning at the primary level. Educational institutions need to set up systems and structures that cater to different gender needs. Curriculum: hanging the language and examples in texts and materials is a good start but needs to be backed up by changes in societal roles. Attitude of the "person in charge" such as the teacher can make a big difference. Should quotas at universities be implemented for girls? What about the places where boys are lagging behind in achievement? Should similar quotas be implemented for boys? Are there good role models for girls and boys? i.e. not just women practicing as lawyers, etc. but that are also active in other areas such as 
technical/vocational and trades, are there useful role models for boys beyond music and sport stars? Poverty and hunger issues need to be addressed alongside gender and health issues as part of a package of social uplift programmes, what is the level of gender sensitization of advocates - i.e. attitudinal change or is it only lip service? A Nigerian colleague summed up the challenges - is it actually possible to eliminate gender discrimination? Are we ourselves accountable or are we only "workshop vanguards" that espouse the values of gender equality because we have attended a workshop or have been advised that gender is a politically correct issue? It is a challenge that we should all reflect upon (summarized by Helena Fehr, commonwealth of Learning, October 2003). Approach to gender equality concern should highlight the importance of asking questions regarding what girls are being taught about themselves in formal schooling, whether education institutions allow girls effective participation and whether the existing situations of girls and women are enhanced or diminished by the schooling they receive. The reasoning underscored is that women and girls are not a single category and care must be taken that a broad range of views of different women and girls are included in curriculum development and review processes. The presence of women in decision-making bodies at national and local government level will have an extremely beneficial effect on shaping a curriculum that is responsive to diverse needs. To add here, a recent seminar/workshop held in London, and entitled "Beyond Access: Curriculum for Gender Equality and Quality Basic Education in Schools" gave rise to a number of clear messages surrounding curriculum and gender equity. A key conclusion, emerging both from the seminar papers and participant's discussion, was that school curriculum is a necessary but not sufficient condition for gender equity in education. For gender equitable education to be possible, change must pursued simultaneously at all levels at all times-girls and boys must be consulted and work must occur with teachers, parents, policymakers and the wider community.

\section{References}

Aidoo A. A. (1998). The African Women Today, In ObiomaNnaemeka (ed.): Sisterhood Feminism and Power from Africa to the Diaspora. Trenton New Jersey: African World Press Inc.

Aina, O. (1998). The silent partners of the women's movement, In ObiomaNnaemeka (ed.): Sisterhood Feminism and Power from Africa to the Diaspora. Trenton New Jersey: African World Press Inc.

Akpan, P. A. (1996). Gender imbalance in access to education: Implications for development in Southeastern Nigeria, In Women, development and the Nigerian Environment. Oruwar Yomi (ed.). Ibadan: Vantage Publishers.

Antai, A. S. and Anam, B. E. (2013). National poverty eradication programme and poverty reduction in Nigeria: empirical investigation of the programme impact in Cross River State. International Journal of Advanced Research in Social Engineering and Development Strategies Vol. 1, No. 1, pp 108-115. 
Asun, C. F., Baklit, G. and Okoye, C. O. (1997). Trends in women education: An analysis of primary, secondary and university enrolment in Nigeria, In Women Development Issues: A book of readings.

Aweda, D. A. (1988). Sociocultural values, sex roles and National Development in Nigeria. Research for Development Journal, Vol.5, No.1.

Aziza, R. O. (1996). Women, politics and the social order. Paper presented at WIN Delta State Branch First Conference. P. T. I. Effurun, September 21.

Bailey, D. V., Basudeb, B., Subal, C. K. and Kris, S. (1987). An analysis of Technical, Allocative, and Scale Inefficiency: The case of Ecuadorian Dairy Farms. Western Journal of Agricultural Economics.

Brigitte, Y. (2001). The mistress and the maid in the globalized economy. Patrick, L. and Leys, C (ed) Socialist Registrar. New York: Monthly Review Press, 1.

Busse, M. (2002). Do labor standards affect comparative advantage in developing countries? World Development.

Clara Osunulu and Felicia DurojaiyeOnyekanmi (eds) The contribution of women to National Development. The Nigerian Association of Nigeria Women (NAUW). International Society-http://www.socialwatch.org/en/informesTematicos/85.html

Denzer, L. (1987). Female employment in the government service of Nigeria. Paper presented at the conference on Women's studies: The state of the act now in Nigeria, Women's Research and Documentation Center, Institute of African Studies, University of Ibadan, Nigeria.

Fafunwa, B. A. (1974). History of Education in Nigeria. London: George Aller and Unwin.

Helena, F. (2003). Commonwealth of learning. Report of the Commonwealth of Nations: Online.

Ighodalo, F. M. (1971). Contributions of women to civil service, In JadesolaAkande, OluremiJegede

Jayati, G. (2001). Globalization, export-oriented employment for women and social policy: A case of India. Geneva: UNRISD

Kaberry, P. M. (1952). Women of the grass fields: a study of economic position of women in Bamenda, British Cameroons. Her Majesty’s Stationery Office, London, United Kingdom.

Kucera, D. (2002). Core labour standards and foreign direct investment. International Labour Review, 141(1-2).

Matata, D. A. and Abdullahi, M. J. A. (2002). Life-long teachers' role, In Refocusing education.

Mba E. N. (1982). Nigerian women mobilized: women's political activity in southern Nigeria, 1900-1965. Berkeley Series, No. 48. Berkeley Institute of International Studies, University of 


\section{Macrothink \\ Journal of Public Administration and Governance \\ ISSN 2161-7104 \\ 2016, Vol. 6, No. 3}

California.

Nkoli, N. E. (2005). Perception of womanhood and the challenge of development. Online.

Ojowu O. (ed). Jos. University of Jos: Centre for Development Studies.

Parrenas, I. (2001). Servants of globalization: women, migration and domestic work. Stanford: Stanford University Press.

Pereira, C. A. Pagnette G. E. Wood P. B. and Grant, S. (1998). Wofe and husband's family planning approval in Nigeria: how influenced by male characteristics, wives authority, and ethnicity. Paper presented in IUSSP Committee on fertility and family planning in collaboration with the African population policy and health research centre seminar on reproductive change in sub-saharan Africa held on 1998, 2-4 ${ }^{\text {th }}$ November, Nairobi.

Robertson, C. (1986). Women's education and class formation in Africa, 1950-1980. In Claire Robertson and Iris Berger (eds.), Women and Class in Africa. New York: African Publishing Company.

Seguino, S. (2000). The Effects of Structural Change and Economic Liberalization on Gender Wage Differentials in South Koria and Taiwan. Cambridge Journal of Economics, 24 (4).

\section{Copyright Disclaimer}

Copyright for this article is retained by the author(s), with first publication rights granted to the journal.

This is an open-access article distributed under the terms and conditions of the Creative Commons Attribution license (http://creativecommons.org/licenses/by/3.0/). 